\section{Information content and informativeness of the analyst report in Malaysia Evidence from Sharĩah-compliant shares}

\author{
Hassanudin Mohd Thas Thaker \\ Department of Economics and Finance, Sunway University, \\ Bandar Sunway, Malaysia, and
Azhar Mohamad, Nazrol Kamil Mustaffa Kamil and Jarita Duasa Kulliyyah of Economics and Management Sciences,
International Islamic University Malaysia, Kuala Lumpur, Malaysia

The analyst report in Malaysia

\title{
Abstract
}

Purpose - This paper aims to investigate the value of information content and informativeness of the analyst report for Shari ${ }^{-}$ah-compliant shares in Malaysia.

Design/methodology/approach - The authors use a sample of 657 daily published analyst reports on Shari ‘ ah-compliant shares from 2010 to 2015, which were downloaded from Bursa Malaysia's repository system. The method was quantitative in nature and panel regression analysis was used. Diagnostics tests including the variance inflation factor, correlation analysis, heteroskedasticity test, serial auto-correlation and the Hausman test were performed to ensure validity and reliability of data. The significance of the variables indicated whether the analyst reports contained valuable information on Shariah compliancy.

Findings - Results obtained from the FEM-Robust model revealed that the $R^{2}$ value was equivalent to 0.79 per cent, suggesting that the power of return explained by the information content and informativeness was less for Shari $a h$-compliant shares. The $F$-statistics were statistically significant for all models, postulating that the data used were reliable and fit for the purpose of analysis. The findings showed that the information content of target price and earnings forecasts significantly influenced the returns of Shari ah-compliant shares. In terms of informativeness, return on equity, sales to price ratio and cash flow to price were associated with the returns of the shares.

Practical implications - The outcome from this finding confirmed that the analyst report retained its position as a good source of reference when making investment decisions. However, the disclosure of information in the form of qualitative information together with fundamental information should be enhanced for Shari $a$ h-compliant share so that investors would have adequate information when making an investment decision.

Originality/value - This study will supply more insights into the matter of information content and informativeness of the analyst report in Malaysia by focussing on Shari ah-compliant shares, which is practically an underexplored research area in Malaysia.

Keywords Malaysia, Information content, Informativeness, Analyst report

Paper type Research paper

\section{Introduction}

The popularity of the Islamic financing industry keeps on increasing and rapidly growing. The growth can be seen from various aspects, starting from financial products to Islamic capital markets. At the end of 2016, the total assets of the world's Islamic finance reached around \$2.1tn (Standard and Poor's Ratings, 2017). The increase in demand for Islamic \section{(1)}


JIABR 11,4 financial products continues to hike all over the world, which has led to such tremendous asset size. The demand for Islamic financial products or Islamic and Sharīah-compliant products is also witnessed among Western countries and cities such as Singapore, London and Hong Kong. These locations have begun to rapidly promote Islamic financial products. In addition, they all compete with existing countries that specialise in Islamic finance such as Malaysia, Bahrain, Qatar and the United Arab Emirates (UAE). Although the growth of the Islamic financing industry appears significant and promising, the issues of product marketability, standardisation of Islamic finance, Shariah compliancy and global market uncertainty remain to haunt the development of Islamic finance in general (Sing and Richter, 2010). Many academic research studies and efforts are carried out and currently taking place to solve the problems identified with Islamic financing products.

One of the hurdles faced by Islamic finance is the marketability of Islamic Shari $a h$ compliant products. The majority of research had been carried out in the context of the conventional framework instead of Sharīah-compliant products. Moreover, Sharīahcompliant products that are available in the market are based on conventional regulation. In other words, a proper benchmark in governing Shariah products has yet to exist. Given this issue, some Sharīah-compliant products are rejected by scholars for their lack of standardisation. As of now, innovation in Islamic financial products is of particular significance with the various innovative financial products introduced in the market. Nevertheless, the issue of standardisation remains a problem. Standardisation in Islamic finance continues to be difficult to implement as different countries practice different laws and regulatory frameworks. According to Sing and Richter (2010), there is the absence of standardisation in Islamic finance. This thus dampens the acceptability and development of Sharīah-compliant products. Another area that challenges the growth of Sharīahcompliant products is the lack of professionals or experts in Islamic finance (Ainley et al., 2007). The problem aside, efforts are being implemented to harmonise and standardised Shari ${ }^{-}$ah-compliant products and to promote them to a wider audience.

If better standardisation takes place in Islamic finance, the financial analysts' recommendation with regard to Islamic Shari $a h$-compliant stocks would, therefore, be of particular interest. Given that financial analysts act as the information intermediary between companies and investors, they should be able to produce valuable recommendations to the investors. Investigating the truthfulness of this statement is, therefore, a concern. Assuming that financial analysts do make valuable recommendations, it would thus be far easier to market Sharī ah-compliant stocks to market players, which will subsequently boost the performance of Shariah stocks. Otherwise, it would have resulted in lower marketability. Looking at the present literature, one thing can be clearly noted, in which the financial analyst will usually come out with a better recommendation for Shari' ${ }^{-}$ah-compliant stocks compared to non-Shariah stocks. According to Farooq (2014), the information environment of the Shari $\bar{t}^{-}$h-compliant firms causes the firms to encounter low levels of leverage and account receivables. Less cash and interest-based securities usually produce better information disclosure. According to Ettredge et al. (2002), one of the main reasons for aggressive accounting policies is mainly due to debt covenants. Thus, firms that have no debt obligation seem less likely to window-dress their earnings presentation. Sweeney (1994) argued that firms, which are engaged in higher levels of debt will most likely manipulate their earnings to avoid debt covenant defaults.

Account receivable also influences the environment of information disclosure. Marquardt and Wiedman (2004) stated that when the account receivable increases, it will result in higher earnings manipulation. Similar to Marquardts and Wiedman's study, Caylor (2010) stands with the argument that in most cases, financial managers will use account receivable 
as a tool to disclose positive earnings surprises. The studies also highlighted that an increase in the level of account receivable allows the management to window dress the accounting information in the statements. The final feature of Shari $\bar{l}^{-}$ah-compliant firms is the amount of cash, which is also one of the important determinants that leads to the overstating of accounting information. In a study by Bukit and Iskandar (2009), it was found that earnings management was relatively good among firms, which had a surplus of cash, which also resulted in the agency problem. This problem allowed managers to take advantage of maximising personal gains, which usually involved negative net present value (NPV) projects. Bukit and Iskandar also revealed that firm managers working in firms with extensive cash surplus tended to use accounting standards or rules to push the earnings by hiding failed projects. To do so, managers would fashion the earnings via accounting discretion. This has similarly been argued by Farooq (2014). Based on the above literature evidence, it can, therefore, be argued that Sharī ah-compliant firms have better information exposure compared to non-Shariah firms.

The studies by Farooq (2014) and Farooq and AbdelBari (2013) postulated that Sharī ahcompliant companies tend to be less involved in earnings manipulation as compared to nonShari $a$ h-compliant firms. Another factor that leads to a better information environment among Shari ${ }^{-} a h$-compliant firms is the extra clientele that they generate from Shariah conscious investors. With a higher clientele, the Sharīah-compliant firms can lower the level of the agency problem. Farooq (2014) argued that the new clientele of Shariah conscious investors can be an important source of monitoring devices. Given this, if the management goes against any of the Shariah characteristics, these investors can exit. Worry about this exit will result in the possibility of the management to retain Shari $a h$-compliant characteristics, thus providing less opportunity for the management to window dress the firm's accounting earnings. Consistent with Farooq (2014), this study also argues that Sharīah-compliant firms practice better information disclosure, which also affects the performance of analyst recommendation. The existing literature has made evident that better disclosure of information will help analysts to produce better recommendations and increase their predictive ability. Byard et al. (2006), as cited in Farooq (2014), stated that analysts will generally issue more accurate information if the firms have better governance and information accessibility. This view is also supported by Ali et al. (2007).

The main area of the current research focuses on the forms of stock markets in the context of Malaysia. The JP Morgan research in 2016 has clearly issued that the performance of Sharīah-compliant stocks was much better compared to non-Shariah stocks. From the perspective of valuation, the value of Shariah stocks was much more robust compared to non-Shariah stocks. This may be due to the fact that Sharī ah-compliant sectors were more diversified in terms of consumer, construction, energy, property, healthcare and others. Another possible reason may be due to investments being made in the belief of faith, signalling faith-based investment. Moreover, the buy-attention for Shariah stocks was possible due to the controlling factor by local institutions in the market.

Given such rapid progression in the capital market, especially for Islamic Shariah shares, it is worthwhile to analyse how financial analysts help to promote market liquidity by disseminating information on stocks to the investors through the analyst report. The role of a financial analyst is essentially crucial to the investors as they will use the analyst report as one of their sources of information or referral when making investment decisions related to stocks. Usually, the analyst analyses various information ranging from the financial and managerial aspects of the company, and will disclose all that information in the analyst report. The analyst will at the end recommend whether to buy, hold, or sell the shares (Baule and Wilke, 2014; Healy and Palepu, 2003). 
JIABR 11,4

By definition, analyst reports involve the collection, analysis and distribution of information pertaining to a firm's current and future prospects. Interestingly, reports published in Malaysia are different from and comparable to other countries. A unique characteristic of the Malaysian analyst report is that it covers both non-Shariah and Shariah firms. The Securities Commission, as well as the Bursa Malaysia, require and encourage the full disclosure of informational liquidity to the investors. The information consists of various aspects such as market outlook, accounting information, information related to economic progress and many others. Moreover, analyst firms in Malaysia are also subject to produce periodic reports when firms make new announcements in the market. Looking at the empirical studies in the field of analyst report, there have been extensive research, which have taken place over the past three decades. A majority of the research zoomed into the stock market's reaction, the information contained in the report, and mainly focussed on non-Shariah firms. Thus, it is of value to carry out further research on this area by looking at Shariah firms and the role of the analyst report, especially in terms of information content.

The present study was inspired by Farooq's (2014) research, which examined the value of recommendation made by analysts for Shariah and non-Shari $a h$-compliant shares in the region of MENA. Results of his study revealed that analysts were able to produce recommendations that generated returns for non-Sharī ah-compliant shares compared to Shari ${ }^{-} a h$-compliant shares. Interestingly, the study also warned investors to not blindly follow the analyst recommendation. This implies that the analyst report does not signal or convey relevant information to the investors, thus the generation of return is not in line with non-Shariah firms. This breakthrough finding by Farooq (2014) contradicts the view of the information signalling hypothesis when it comes to the analyst report and Shari $a h$ compliant shares[1].

Hence, the present research aims to look at the Malaysian context and the role of the analyst report in the market, especially for Sharīah-compliant shares. To distinguish itself from the study conducted by Farooq, this research only uses Shar $\bar{l}^{-}$ah-compliant shares recommended by analysts. Furthermore, the value of the recommendation is measured by the information contained in the analyst report. Thus, this study will look into the influence of information contained on the return of Sharī ah-compliant shares.

This study claims two major contributions. Firstly, it enriches the literature available in the context of analyst reports and Sharīah-compliant shares. At present, limited studies have been done on the analyst report and Shariah shares in Malaysia. Studies that were conducted were also diverse in nature. For example, Hatamleh and Salameh (2012) did a study focusing only on corporate social responsibility (CSR) and the role of analyst reports. Farooq (2008) performed a study on the financial crisis and the analyst report. Madun (2009) looked into analyst incentive and analyst prediction, whereas Wahab et al. (2015) investigated corporate governance, culture and analyst forecast. Yezegel (2015), on the other hand, investigated the value of analyst recommendation ratings. These are some of the available research studies found in the context of the Malaysian market. It is apparent that limited research, if any, has been carried out in the scope of Shari ah-compliant shares. Given this, the present study expects to provide a deeper insight into the role of analyst report towards Shari $a h$-compliant shares, subsequently enriching the existing literature. Secondly, the study claims its contribution in terms of investment strategies. As information content significantly influences stock returns, this study is expected to help investors in designing better investment strategies that will enhance their investment decisions. 


\section{Review of literature}

In recent years, the growth of Islamic finance has been tremendously good and in line with the development of conventional finance. The expected size of the Islamic finance industry is projected to reach $\$ 3.4 \mathrm{tn}$ by the end of 2018 . The Islamic finance industry has reached $\$ 1.88$ to $\$ 2.1$ tn based on the most current account given (Islamicfinance.com, 2016). In a report published by Earnst and Young Report (2016), the growth of Islamic financing assets was above 40 per cent in 2016. In the Malaysian capital market, Islamic compliant securities recorded a total value of US\$342.7bn at the end of quarter one in 2016, which was the highest for any exchange globally.

Given the rapid progression of the Islamic finance industry, it is vital to see how faithbased investment is also progressing. The matter of Shariah is a key point when making investments in the equity market. Some investors place more importance on religious aspects when dealing with investment activities. Therefore, it is worthwhile to investigate how investors who are concerned about Shariah matters make investment decisions. One of the ways to achieve this is by following the analyst report. In general, the report published by the financial analyst plays a crucial role in disseminating all information related to a company to the investors. Theoretically speaking, full disclosure of information leads to information efficiency and helps in price discovery. Furthermore, the analyst employs various techniques to analyse the firm value which helps investors make informed decisions on stock investments.

A large number of literature have made concrete discoveries on the matter of information content and the analyst report. For instance, the top highly cited research in the context of analyst report, namely, Womack (1996), Jegadeesh et al. (2004) and Asquith et al. (2005), documented that the disclosure of information in the analyst report played a significant role in enhancing the decision making process related to investment in shares. These studies argued that analyst recommendation added value to the investment and minimised the issue of asymmetric information. Given this, the financial analyst should be able to provide good recommendations and better information disclosure towards Sharī ah-compliant shares due to their low leverage, low account receivables and interest-bearing securities compared to non-Shariah stocks (Farooq, 2014).

The literature on information content and analyst report is largely available for nonShari $a h$-compliant shares as opposed to Sharī $a h$-compliant shares. Plus, a majority of the studies were carried out in the Western context instead of emerging markets. For example, Womack (1996) investigated the issue of price drift when the recommendation was out and post-recommendation. The result found a strong existence of price drift for the analyst recommendation. However, this depended on whether the information was positive or negative. Womack argued that recommendations that were good (bad), favourable and positive encouraged the investor to buy (sell) the shares in particular and generated significant abnormal returns (losses). The same finding has also been reported by Guagliano et al. (2013) and Da and Schaumburg (2011). This suggests that the analyst report contains valuable information which enhances returns to the investors.

Following Womack, Asquith et al. (2005) analysed a number of 1,126 analyst reports published by 56 "First Team" from the All American Institutional Investor. The study showed that a majority of the information content associated with stock returns. Furthermore, investors tended to react with the changes in vocabularies, such as the positive or negative tone. The outcome of Livnat and Zhang's (2012) study agreed with Asquith et al.'s, in which the result postulated that about 78.5 per cent of investors relied on public news in analyst reports in making an investment decision, which was also in line with the analyst's information elucidation role. Although both of these studies concluded similarities 
JIABR 11,4

with regard to the role of the analyst report and information content, both of these studies were restricted in terms of the variables used (i.e. target price, earnings forecast and size and volume) as information content. Moreover, the studies focused on developed markets instead of the emerging market.

Chang and Chan (2008) measured the information content of recommendation revision and its relationship with stock price reactions. Using event study and ordinary least square (OLS) analysis, the authors proved that there was a strong association between recommendation revision and stock price movement, especially for recommendations, which involved upgrade recommendation. In contrast with Chang and Chan, Da Silva's study concluded that the information content of target price, earnings forecast, and recommendation revisions did not affect the abnormal return and had less predictive power in explaining the movement of stock prices. This is similar to Bradshaw and Brown's (2006), in which their study suggested the less predictive power of information disclosure, which was perhaps due to the analysts' lack of skills. The authors also argued that the analyst who is an expert in forecast ability would not necessarily produce recommendations which could bring favourable results.

In addition, Jegadeesh and Kim (2006) looked into the role of analyst recommendation in the G7 countries. The findings revealed that except for Italy, the stock price movement was statistically significant when recommendations were made by analysts for the countries. The elasticity of price responsiveness in the analyst report showed that there was the existence of value in the recommendations made by analysts. This result is similar to Brav and Lehavy (2003) and Francis and Soffer (1997). Contradicting the others, Savor (2012) aimed to document the relationship between the information content of trading volume with price drift for the year 1995 until 2009. Together with trading volume, the study also incorporated a few control variables such as stock return and firm size. The result indicated that investors would under-react to the information contained in the analyst report and overreact to the non-fundamental information that influenced stock prices.

The debate is nevertheless ongoing, with some arguing that the information disclosure in the analyst report does not fully incorporate all available information for non-Shariah firms. For example, in a study performed by Thaker et al. (2017), it was revealed that a majority of analyst reports for non-Shariah stocks lacked information disclosure, especially qualitative information, as they were largely based on quantitative or statistical properties. This observation is consistent to that of Breton and Taffler (2001). The authors argued that fundamental information, such as balance sheet measures, had lesser robust power. As an alternative, the authors suggested the incorporation of qualitative variables, which might directly affect stock prices and corporate management strategies. The same view is shared by Cheynel and Levine (2012).

The existing literature has also argued that information disclosure will positively influence Shari ${ }^{-}$h-compliant shares. This is because Shariah compliancy has to be in line with the requirement of Shariah rules. Hence, there must be a clear disclosure of information. In the study investigated by Farooq and AbdelBari (2013), it was revealed that Shari' ${ }^{\prime} a$-compliant firms had better information disclosure because they were involved in fewer earnings manipulation compared to their non-Shariah counterparts. Good information disclosure helps analysts to produce recommendations, which are accurate as a result of good governance practices and mechanisms. The forecast accuracy by analysts also increases and results in profitable recommendations when the firm practices good information disclosure. This view is shared in the studies by Loh and Mian (2006) and Ertimur et al. (2007). Farooq's (2014) study further confirmed this stance by stating that better disclosure allows the analyst to produce value-relevant recommendations. 
Academic research on information content have been mainly carried out using samples of companies from the USA, with the following majority involving samples from advanced countries such as the UK, Japan, Australia, and others with less focus and attention given to the context of Malaysia. However, this does not imply a total absence of similar studies in Malaysia, as a number of academic dissertations and articles have been successfully located in the local context. They include those which were done to discuss the different aspects of the analyst report. Moreover, strikingly limited research has explored the information contained in analyst reports in the local setting. Studies by Madun (2009), Hatamleh and Salameh (2012), Wahab et al. (2015) and Yezegel (2015) are among the best examples of research which have dealt with the matter in the Malaysian market.

Madun's (2009) dissertation vitally focussed on the magnitude of the effects of incentive schemes on analyst coverage among companies participating in the scheme. In other words, Madun's research examined whether the schemes given to analysts reduced the level of asymmetric information in the market. Using Kyle's 66 models, the study incorporated various variables such as stock return, the volume of shares, bid and asks spread, price impact frequency and private trading volume in measuring asymmetric information. The results of the regression analysis proved that analyst coverage schemes did not fully result in heightening investor impacts. The statistical relationship showed an insignificant relationship between the variables. The research also hypothesised that analyst reports significantly benefitted certain markets and did not benefit other markets. The advantage of this research was that it explored the subject matter from the context of the Malaysian market by analysing the analyst report and incentive coverage schemes. However, this research was limited in that it concentrated on analyst coverage incentives instead of information content. The study also used trading volume as information contained in the report by ignoring other elements that might significantly affect or could possess predictive power in the analyst report. Additionally, it did not take into account the Sharī ah-compliant stock in the analysis.

Hatamleh and Salameh's (2012) dissertation on 123 public-listed companies investigated the relationship between corporate social responsibilities (CSR) and analyst recommendation. Typically, companies, which emphasised CSR in business activities received high recommendations from the analyst. In the context of Malaysia, the study found the presence of a significant relationship between CSR and analyst coverage recommendation, as Malaysian companies mainly published their CSR activities to the public, hence the public's awareness over the matter was significantly high. This finding was also consistent with the study by Ioannou and Serafeim (2010). Similar to Hatamleh and Salameh (2012), Wahab et al. (2015) also conducted research on analyst recommendation, but with reference to corporate governance, culture and analyst forecasts. The objective of their study was to test the relationship between culture, corporate governance, and analyst forecast among Bumiputra-listed companies within a time span of 1999-2009. With an observation sample of 664, the authors claimed the existence of a positive relationship between culture and analyst forecast, but less association between corporate governance and analyst forecast error. Although both of these studies thoroughly examined the area of analyst report, minimal focus was given to the information content of the report on Shariah stocks. Taking this issue into account, the present study extends further its contribution towards the body literature by documenting the effect of information contained in the analyst report by looking into the context of Malaysian Shariah stocks.

To conclude the literature review section, it can be clearly seen that almost all of the studies to date tended to focus on the relationship between information content and stock returns. A majority of the studies merely focussed on non-Shariah companies instead of 
JIABR 11,4 their Shariah counterpart. Moreover, the literature available mainly concentrated on the Western context and the MENA region, with limited research carried out in Asian countries. Furthermore, although extensive researches have empirically investigated the field of analyst report, there is no clear consensus when it comes to the value of recommendation given by the analyst. The findings have so far been directed by mixed results. Thus, it remains worthwhile to investigate the matter of information content and its relationship with stock returns, in particular, Sharī ah-compliant shares.

\section{Methodology and hypotheses development}

This study follows the quantitative research design as it involves several empirical investigations. It focusses on analyst recommendations for KLSE-listed companies on a daily basis, covering from the year 2010 till 2015. The analyst reports were gathered from the Bursa Malaysia repository system. The underlying stock prices, Kuala Lumpur Composite Index (KLCI) points, and trading volume were obtained from Datastream. Overall, a total of 850 reports were collected. However, only 657 reports were used as some of the reports were excluded due to the unavailability of recommendations during the period covered. This scenario was observed when certain companies underwent changes, such as delisting from Bursa Malaysia, merger and acquisition (M\&A), change in ownership, etc. In addition, some of the required information was not available in Datastream. Hence, the reports given to such exemption were also excluded. In some cases, some of the analyst reports had to be excluded because they were concerned with non-Shariah firms. This study, on the other hand, is only concerned with Shari ${ }^{`} a h$-compliant companies. Furthermore, even though analyst reports usually include recommendations regarding buying, holding and selling, for the purpose of analysis, this research simply uses recommendations involving selling.

The variables chosen for the study are divided into two parts, namely, information contents and informativeness, extracted purely based on the literature evidence. The variables on information contents include target price, earnings price and trading volume. The variables of informativeness are ROE, DPS, EPS, SPKLCI, CFP, SPR, MBV, MC, P/E, $\mathrm{SA}$, Pages and SH. Further details of the variables are given in Table I.

The hypotheses developed in this study are disclosed in Table II.

In analysing the information contained in the analyst report, this research applies the panel regression analysis (Feng et al., 2015; Huang et al., 2009). The panel regression analysis has been widely applied in various investigations related to the predictive power and information content of analyst reports. Panel data analysis was employed due to the nature of the data, which involved a daily basis and cross-sectional data. According to Lien and $\mathrm{Li}$ (2013), there is an increased awareness of the benefits of panel data analysis over cross-sectional and time-series data. Due to that, the data sets were analysed based on different time horizons and categorical variables. Moreover, the literature has also made evident that the panel data analysis will help avoid unobservable individual heterogeneity. The panel regressions analysis was also used to discover the association between the explanatory variables with abnormal stock returns due to the announcement effect in the capital market. To see consistency in the results, this study also included pooled regression for the purpose of comparison. However, the final results and discussions of the model are based on the Hausman test.

Calculation of the cumulative abnormal return (CAR) closely followed a similar approach to Chen and Chu (2009) and Huang et al. (2009), which was based on market-adjusted return. First, the raw return was computed for each recommendation. The daily abnormal return (AR) was calculated as follows: 


\begin{tabular}{ll} 
Variables & Definition \\
\hline TR & Reflects the target price derived by the analyst on day $i$-th \\
EF & Indicates the earnings forecast on day $i$-th \\
TVOL & Shows the current trading volume on day $i$-th \\
ROE & Return on equity measures the progress of company profitability \\
DPS & Reflects dividend per share \\
EPS & Reflects earnings per share \\
SPKLCI & Share price relative to KLCI \\
CFP & Represents cash flow to price \\
SPR & Represents sales price to ratio \\
MBV & Reflecting market to book value \\
MC & Shows the market capitalisation of the companies \\
P/E & Reflects the willingness of investors to pay for the shares \\
SA & Number of analysis used in the analyst report \\
Pages & The number of pages reflects the amount of information content disclosed to the investors \\
SH & The number of shareholder is also important as it signals the overall progress of the company \\
& and its strength. As for this, it is proxy by the number of shareholders
\end{tabular}

Notes: This table shows the variables used in the research. The variables are divided into two categories, firstly, the information content proxied by TP, EF and TVOL and secondly, the informativeness proxied by ROE, DPS, EPS, SPKLCI, CFP, SPR, MBV, MC, P/E, SA, Pages and SH

Table I.

Definition of variables

$$
\overline{A R}=\sum_{t=1}^{n}\left(R_{i, t}-R_{m, t}\right)
$$

where:

$R_{i, t}=$ to the return of stock, whereas $R_{m, t}$ is the KLCI index return.

To calculate the daily basis stock returns, the following formula was used:

$$
R_{i, t}=\frac{D_{i, t}+P_{t 1}-P_{t 0}}{P_{t 0}}
$$

where:

$D_{i, t}=$ dividend received during day $t$;

$P_{t 1}=$ the current stock price during day $t$; and

$P_{t 0}=$ the stock price for the day before $t$.

To calculate the market return, the following equation was used:

$$
R_{m, t}=\frac{\text { KLCIindex }_{t 1}-\text { KLCIindex }_{t 0}}{\text { KLCIindex }_{t 0}}
$$

where

KLCIindex $_{t 1}=\mathrm{KLCI}$ index value for day $t$; and

KLCIindex $_{t 0}=$ KLCI index value for the day before $t$.

The final process was to calculate the CAR for day $t$ as:

$$
C A R_{t}=\sum_{n}^{t} \overline{A R_{T}}
$$




\section{JIABR 11,4}

No. Hypothesis

1 An information content on target price has significant relationship with the Cumulative Abnormal Return (CAR) of Sharī ah-compliant stocks

2 An information content on earnings forecast has significant relationship with the Cumulative Abnormal Return (CAR) of Shari ${ }^{-}$ah-compliant stocks

3 An information content on trading volume has significant relationship with the Cumulative Abnormal Return (CAR) of Sharì ah-compliant stocks

4 The informativeness of ROE has significant relationship with the Cumulative Abnormal Return (CAR) of Shari ${ }^{-}$ah-compliant stocks

5 The informativeness of DPS has significant relationship with the Cumulative Abnormal Return (CAR) of Sharī ah-compliant stocks

6 The informativeness of EPS has significant relationship with the Cumulative Abnormal Return (CAR) of Sharī ah-compliant stocks

7 The informativeness of SPKLCI has significant relationship with the Cumulative Abnormal Return (CAR) of Sharī ah-compliant stocks

8 The informativeness of CFP has significant relationship with the Cumulative Abnormal Return (CAR) of Sharī ah-compliant stocks

9 The informativeness of SPR has significant relationship with the Cumulative Abnormal Return (CAR) of Sharī ah-compliant stocks

10 The informativeness of MBV has significant relationship with the Cumulative Abnormal Return (CAR) of Sharī ah-compliant stocks

11 The informativeness of MC has significant relationship with the Cumulative Abnormal Return (CAR) of Sharī ah-compliant stocks

12 The informativeness of P/E has significant relationship with the Cumulative Abnormal Return (CAR) of Sharī ah-compliant stocks

13 The informativeness of SA has significant relationship with the Cumulative Abnormal Return (CAR) of Sharī ah-compliant stocks

14 The informativeness of pages has significant relationship with the Cumulative Abnormal Return (CAR) of Sharīah-compliant stocks

15 The informativeness of SH has significant relationship with the Cumulative Abnormal Return (CAR) of Shari ah-compliant stocks

Table II.

Hypotheses development
Notes: This table shows the hypotheses generated to meet the research objective. Overall, fifteen hypotheses were developed and tested in this study

Following the completion of CAR calculation was the development of the model. The panel techniques consisted of two regression models, which were the fixed effect model (FEM) and the random effect model (REM). To select the best model from these two models, this study subjected itself to the Hausman test. The research adopted the following regression equation:

$$
\begin{aligned}
C A R_{i, t}= & \beta_{0}+\beta_{1 i}(\mathrm{TP})_{1 \mathrm{i}}+\beta_{2 \mathrm{i}}(\mathrm{TP})_{2 \mathrm{i}}+\beta_{3 i}(\mathrm{TVOL})_{3 \mathrm{i}}+\beta_{4 i}(\mathrm{ROV})_{4 \mathrm{i}}+\beta_{5 i}(\mathrm{DPS})_{5 \mathrm{i}} \\
& +\beta_{6 i}(\mathrm{EPS})_{6 \mathrm{i}}+\beta_{7 i}(\mathrm{SPKLCI})_{7 \mathrm{i}}+\beta_{8 i}(\mathrm{CFP})_{8 \mathrm{i}}+\beta_{9 i}(\mathrm{SPR})_{9 \mathrm{i}}+\beta_{10 i}(\mathrm{MBV})_{10 \mathrm{i}} \\
& +\beta_{11 i}(\mathrm{MC})_{11 \mathrm{i}}+\beta_{12 i}(P / E)_{12 \mathrm{i}}+\beta_{13 i}(\mathrm{SA})_{13 \mathrm{i}}+\beta_{14 i}(\mathrm{Pages})_{14 \mathrm{i}} \\
& +\beta_{15 i}(\mathrm{SH})_{15 \mathrm{i}}+\boldsymbol{\varepsilon}_{i}
\end{aligned}
$$

Furthermore, batteries of diagnostics tests were also performed to check the reliability and validity of the data used in the research. The diagnostics tests included the variance inflation factor (VIF), correlation analysis, heteroscedasticity test, serial auto-correlation and 
the Hausman test. The result from the unbalanced panel data revealed that not all of the information contained in the analyst report was able to detect stock returns movement. In the event where serial correlation and heteroscedasticity issues were observed, the study ran the model with robust standard errors.

The analyst report in Malaysia

\section{Diagnostic tests, descriptive statistics and discussion of findings}

\subsection{Diagnostic tests}

The research began with several diagnostic tests to ensure that the data were fit for the research purpose. In terms of the VIF test, a majority of the variables scored the mean value of less than 10.00, indicating that there was no issue of multicollinearity. The overall mean for VIF was just 1.15, which was less than 10.00, further confirming that there was no issue with the data used. The correlation analysis was significant to see the degree of one variable to linearly relate to another variable. The matrix of correlation also postulated the issue of collinearity, similar to the VIF. From the result of correlation analysis, it can be clearly noted that all of the correlation values were lesser than 70 per cent (rule of thumb), indicating that there was no multicollinearity problem in the model (Table IV). Thus, the variables were fit for running the analysis.

The next step was to test for heteroscedasticity in checking for variation of error terms across the number of observations. To perform this, the research deployed the Breussh Pagan or Cook-Weisberg test. The $p$-value $(0.000)$ for this test significantly postulated that there was the issue of heteroskedasticity in this model. Case in the hold, the following process was to determine whether the data encountered the issue of serial auto-correlation or not, hence the Wooldridge test was used. The $p$-value was found to be significant (0.0237), indicating the presence of serial correlation in the model. Thus, to deal with heteroscedasticity and serial-autocorrelation issues, the model ran the robust standard errors. Finally, to select the best model between the FEM and random effect (REM), the study applied the Hausman test. A result of this analysis revealed that the FEM was appropriate as the $p$-value was significant. Therefore, a discussion of the analysis will be based on the FEM model.

\subsection{Descriptive statistics}

Table III presents a summary of the model's statistics. Apparent is that the wide differences for variables TP (min:0.01, max:73.15), DPS (min:0.00, max:61.00), EPS (min:0.015, max:91.00), CFP (min:0.00, max:31.90), SPR (min 0.00, max:25.70), SA (min:1.00, max:16.00) and Pages (min:1.00, max:9.00). All of this information contained a degree of value in influencing the return of stocks as revealed by the large difference for Shari $a h$-compliant shares. The rest of the variables were found to score minimum and maximum values, which were relatively fine. The rest of the variables were found to score both minimum and maximum values, which were also relatively fine. Out of 16 variables in the model, some variables scored relatively higher in terms of mean and they were TP (7.67), TVOL (12.94), ROE (8.78), DPS (7.09), EPS (6.21), CFP (8.36), MC (7.46) and P/E (16.23). The variables that scored less in terms of mean were CAR (0.67) and SH (0.67). The others obtained relatively fine mean values. From the perspectives of VIF test, the majority of the variables scored the mean value of less than 10.00 , indicating that there is no issue of multicollinearity. The skewness and kurtosis probability values are more than 5 per cent for each variable, thus the null hypothesis was accepted as the data was normally distributed (Table IV). 


\begin{tabular}{llrrrrrrr}
\multirow{2}{*}{$\begin{array}{l}\text { JIABR } \\
11,4\end{array}$} & Variables & Mean & SD & Minimum & Maximum & VIF & Skewness & Kurtosis \\
\cline { 2 - 8 } & CAR & 0.67 & 2.75 & -14.85 & 15.81 & 1.15 & 0.55 & 8.92 \\
& TP & 7.67 & 13.78 & 0.01 & 73.15 & 1.36 & 3.25 & 10.55 \\
& EF & 3.05 & 9.03 & -34.30 & 79.00 & 1.04 & 1.79 & 15.26 \\
TVOL & 12.94 & 2.41 & 5.70 & 17.92 & 1.31 & 0.44 & 0.20 \\
$\mathbf{8 8 0}$ & ROE & 8.78 & 12.31 & -42.00 & 76.40 & 1.13 & 1.59 & 7.87 \\
& DPS & 7.09 & 7.39 & 0.00 & 61.00 & 1.08 & 2.65 & 12.84 \\
& EPS & 6.21 & 6.17 & 0.01 & 91.00 & 1.03 & 1.33 & 1.96 \\
& SPKLCI & 1.75 & 5.23 & -26.20 & 24.30 & 1.07 & 0.63 & 3.48 \\
CFP & 8.36 & 6.79 & 0.00 & 31.90 & 1.04 & 0.94 & 0.04 \\
& SPR & 4.24 & 4.99 & 0.00 & 25.70 & 1.06 & 1.97 & 3.78 \\
& MBV & 3.72 & 5.10 & -10.20 & 36.73 & 1.14 & 3.03 & 11.74 \\
& MC & 7.46 & 2.52 & 0.41 & 14.94 & 1.61 & 0.37 & 0.74 \\
& P/E & 16.23 & 8.34 & -0.60 & 46.60 & 1.13 & 0.55 & 0.32 \\
& SA & 5.40 & 2.14 & 1.00 & 16.00 & 1.15 & 0.48 & 1.08 \\
& Pages & 3.54 & 1.58 & 1.00 & 9.00 & 1.11 & 1.32 & 1.68 \\
SH & 0.67 & 2.75 & 1.00 & 15.00 & 1.04 & 1.12 & 2.26
\end{tabular}

Table III.

Summary of statistics
Notes: This table presents a descriptive summary of statistics for the model. The time framework used was a daily basis spanning from January 2010 until December 2015. The analyst reports were downloaded from the Bursa Malaysia repository system. The Cumulative Abnormal Return was calculated based on the market-adjusted model. The number of observations was 657

\subsection{Discussion of findings}

As mentioned earlier, the discussion of the study's findings will be based on the FEMRobust analysis. Based on the FEM-Robust analysis, the $R^{2}$ value for the model was equivalent to 0.79 per cent, revealing that the power of return explained by information content and informativeness was low for Sharīah-compliant shares. In other words, other factors may likely influence the return of Shariah shares instead of the information disclosed in the report. The $F$-statistics were statistically significant for all models, postulating that the data used in the study were reliable and fit for analysis.

In terms of the information contained in reports for Shari ah-compliant shares, target price (TP) and earnings forecast (EF) were found to be statistically significant. The TP significance was at 5 per cent whereas the EF significance was at 10 per cent. The result of FEM-Robust showed that TP had a negative relationship with the CAR. This result is consistent with the finding of Da Silva (2013), in which TP was shown to have an inverse relationship with the CAR as it lacked accuracy, thus was not really representing the information content. This finding is also supported by Bradshaw and Brown (2006), in which the authors elaborated that the reason for the negative relationship between the target price and CAR was due to analysts' lack of skill in deriving target price. This subsequently caused a lack of predictive power, especially in the target price. Furthermore, Asquith et al. (2005) argued that other than target price and earnings forecast, other information content tended to be more robust in explaining the return behaviour. The authors also argued that information such as the strength of the analyst, market information, management information and many others had higher influence over return. Thus, for Sharīahcompliant shares, TP was found to be statistically significant to the return. In addition, the information content of $\mathrm{EF}$ had a positive relationship with the $\mathrm{CAR}$, revealing that a higher EF led to a higher return for Sharĩ ah-compliant shares. One of the possible reasons for this may be due to the fact that the EF reflected the profitability of the firms and this signalled positively to the investors, thus inducing them to invest. This result has also been proven in 


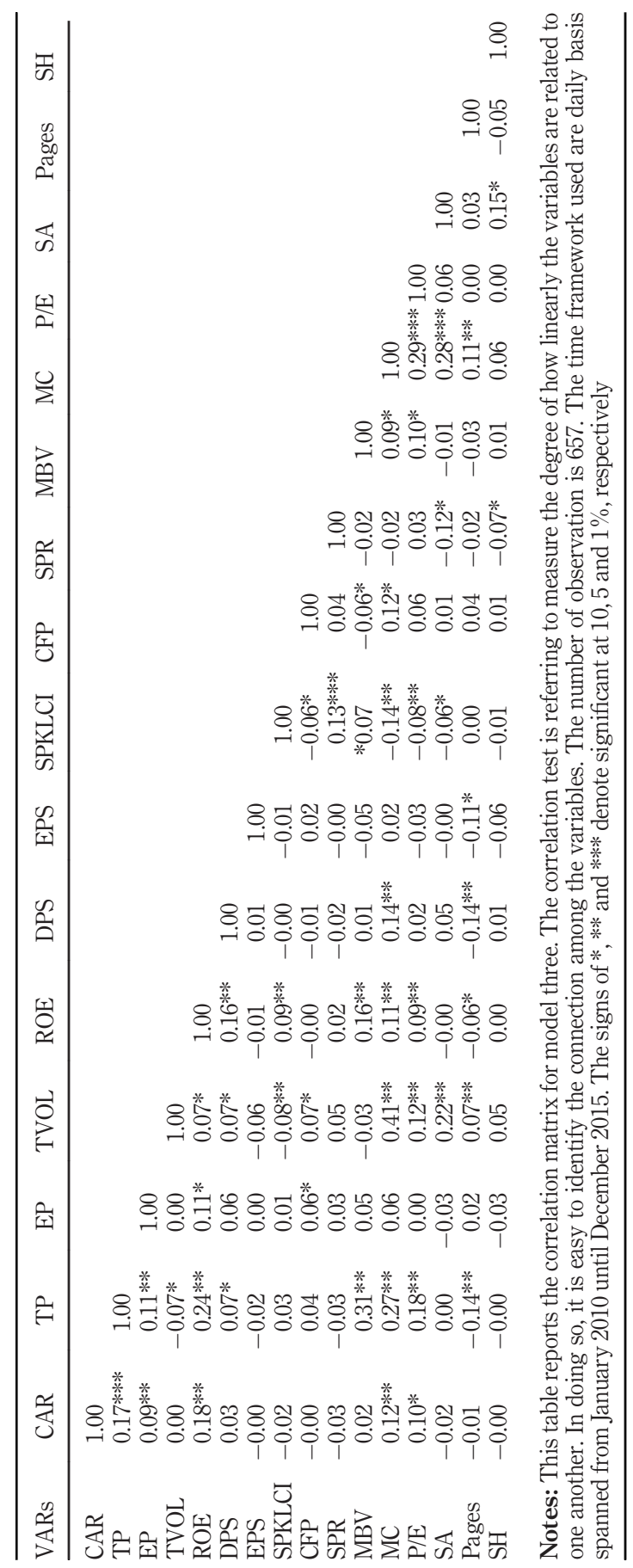

The analyst report in

Malaysia

881

Table IV. Correlation matrix 
JIABR 11,4 earlier studies. For example, in a study performed by Hou et al. (2014), the authors postulated that positive earnings forecast together with a positive upgrade on earning forecast built investor confidence towards a firm's stock performance and subsequently led to a positive gain. This is also supported by the findings of Fama (1984) and Ali and Zarowin (1992).

The variables of ROE, CFP and SPR, measuring informativeness, were found to be statistically significant to the CAR. ROE had a positive relationship with the CAR, indicating that firms that had a good level of profitability led to an increase in share price (Jegadeesh and Titman, 2001; Chan et al., 1991). Unfortunately, this may not be true for all cases as the matter depends on the investors or the way investors interpret the information. For example, some groups of investors may place a high priority on the dividend payment and cash flow stability in seeing the overall progression of the company. In a study done by Fonseka and Tian (2011), ROE was found as less significant with the return as investors placed higher importance to the dividend per share. The study concluded that when it came to investment decisions it was entirely dependent on the way investors read and processed the information. This view is also in line with a study conducted by Mun and Thaker (2016), in which the authors attempted to investigate the asset and liability management of Islamic banking in Malaysia using ROE as the main proxy. The results suggested that when investors analysed Islamic banking, there were many other factors to be considered apart from the ROE. The study also concluded that bank-specific factors were more influencing towards the volatility in the ROE.

The informativeness of CFP and SPR negatively associated with the CAR of Shariah compliancy. The CFP and CAR had an inverse relationship, perhaps caused by systematic volatility and idiosyncratic risk that affected the valuation. Because of this, when CFP valuation was higher (lesser), this led to a decrease (increase) in stock prices. This point is supported by the findings of Huang et al. (2009) and Irvine and Pontiff (2009). Although this study has demonstrated that the CFP negatively associated with the CAR, a majority of the existing literature claimed a positive relationship. For example, in the studies performed by Atieh (2014), Parnal and Jain (2013) and Jooste (2007), the researchers found that CFP had a positive relationship with the return and had predictive power in explaining the return movement.

Together with CFP, SPR was also observed having a negative association with the CAR of Shari ${ }^{-} a h$-compliant shares. This result is consistent with the study performed by Lau et al. (2002), in which the authors found a conditional negative relationship between stock price and sales to price ratio in Malaysian and Singaporean markets (Shariah and nonShar $\bar{l}^{-}$ah-compliant shares). The study indicated a negative association between return and sales growth in Singapore. In a study carried out by Mburu (2014), the finding revealed an interesting outcome. Low sales to price ratio appeared to encounter higher returns in recent decades, especially for short and medium age firms. However, the author argued that this finding was subject to controversy as there were many inconsistencies in terms of justification in the present literature.

One of the literature that showed inconsistency in the results was the research conducted by Dewi and Ferdian (2012), which was mainly based on the context of the Indonesian market and focused on Shari ${ }^{-} a h$-compliant shares. The authors aimed to investigate the variables that influenced the return of firms using the Fama and French model. Employing many control variables, including valuation factors, the authors found the most influencing factors in return were firm size, book to market ratio and firm beta. Other variables were observed to have less power in affecting the return. 
Furthermore, other models were incorporated into the current study to capture the consistency of results among other models. Referring to Table III, POLS and REM are shown to reveal different outcomes. The $R^{2}$ value for both models was 7.23 per cent, which was higher than the FEM model. Comparing the $R^{2}$ values with FEM explains that the influence of the variables towards stock return remained low. In terms of information contained in the analyst report, again the TP was shown to be significant, and the coefficient sign was positive. In other words, a higher TP resulted in a higher CAR. This finding is consistent with the findings by Barber et al. (2007) and Jegadeesh and Kim (2006). These two studies concluded that TP positively related to stock return with high elasticity. This is because TP estimation takes into account all the positive aspects of the firms. Therefore, this conveys a good signal to the investors and induces them to invest in the firm's stock (Guagliano et al., 2013; Da and Schaumburg, 2011; Asquith et al., 2005). Furthermore, this also shows that the MC has a positive association with stock return. Usually, the size of a firm is proxy to market capitalisation, reflecting the overall progression of the firm. Many analysts also place higher importance to the element of firm size as it captures the entire liquidity of information required by investors in valuing the firm (Hsieh et al., 2005; Jegadeesh et al., 2004; Hodgkinson, 2001; Brennan et al., 1998; Bhushan, 1989; Foster et al., 1984). This is also true in the context of Shari ${ }^{\circ}$ ah-compliant shares.

As a concluding remark for the findings, it can be clearly noted that not all information content and the informativeness of analyst report had predictive power in explaining the return of Shari ${ }^{-} a h$-compliant shares. Based on the main model, namely, the FEM-Robust, only TP, EF, ROE, CFP and SPR were found to have a relationship with the CAR. Thus, the analyst recommendation seems to be less valuable when in the Malaysian context for Shariah compliancy. Table V presents results for the information content and the informativeness of the analyst report recommending Shariah shares in Malaysia.

\section{Conclusion}

This research aimed to document the information content of analyst reports in the context of the Malaysian market, which covered only Sharīah-compliant shares. The research looked into the value of information content and other variables of informativeness in analyst reports which recommend Shari ${ }^{-} a h$-compliant shares and their relationship with the cumulative abnormal return. Furthermore, the research also looked into the aspect of recommendation accuracy to support the findings. The time framework involved was from 2010 until 2015, containing reports that were published on a daily basis.

The panel results proved that not all information and variables of informativeness relate to the CAR of Shariah shares. Only TP, EF, ROE, CFP and SPR statistically related to stock returns, while the other variables were not. Consistent with the existing literature, the research findings revealed that the analyst report had no value in explaining return behaviour (Farooq, 2014; Jegadeesh et al., 2004). Further justification by Francis and Soffer (1997) also supports the research findings of the current research. This study argues that the analyst reports failed to deliver full information disclosure, which could explain the return movement, thus encouraging investors to refer to their own source of information in making an investment decision.

This is obviously a surprising result, especially for Shari ah-compliant shares, as the shares tend to have a better environment for information disclosure. The result of this research hence suggests that analysts should take the necessary action to further enhance the information disclosure of Shariah stocks. In Malaysia, a majority of analyst reports purely disclose quantitative information alone and disregard qualitative information. This may be the reason why information content and other informativeness have less influence overstock returns. Moreover, this evidence further shows that fundamental information will 


\section{JIABR 11,4}

\begin{tabular}{|c|c|c|c|c|c|}
\hline \multirow{2}{*}{$\begin{array}{l}\text { JIABR } \\
11,4\end{array}$} & & \multicolumn{4}{|c|}{ Dependent variables (CAR) } \\
\hline & Independent variables & POLS & FEM & FEM-Robust & REM \\
\hline \multirow{18}{*}{884} & $\mathrm{TP}$ & $0.0232 *(0.0088)$ & $-0.1500 * *(0.0507)$ & $-0.1500 * *(0.0406)$ & $0.0232 *(0.0088)$ \\
\hline & $\mathrm{EF}$ & $0.0185(0.0118)$ & $0.0322 * *(0.0136)$ & $0.0322 *(0.0176)$ & $0.0185(0.0118)$ \\
\hline & TVOL & $-0.0273(0.0496)$ & $0.0159(0.0658)$ & $0.0159(0.0915)$ & $-0.0273(0.0496)$ \\
\hline & ROE & $0.0344 * * *(0.0090)$ & $0.0436 * * *(0.0116)$ & $0.0436 * * *(0.0116)$ & $0.0344 * * *(0.0090)$ \\
\hline & DPS & $-0.0029(0.01477)$ & $0.0005(0.0188)$ & $0.0005(0.0200)$ & $-0.0029(0.0147)$ \\
\hline & EPS & $-0.0019(0.0173)$ & $-0.0174(0.0218)$ & $-0.0174(0.0349)$ & $-0.0019(0.0173)$ \\
\hline & SPKLCI & $-0.0154(0.0208)$ & $0.0111(0.0242)$ & $0.0111(0.0196)$ & $-0.0154(0.0208)$ \\
\hline & CFP & $-0.0124(0.0157)$ & $-0.0313 *(0.0188)$ & $-0.0313^{* *}(0.0156)$ & $-0.0124(0.0157)$ \\
\hline & SPR & $-0.0187(0.0216)$ & $-0.0599 * *(0.0264)$ & $-0.0599 * *(0.0235)$ & $-0.0187(0.0216)$ \\
\hline & MBV & $-0.0326(0.0219)$ & $-0.0077(0.0246)$ & $-0.0077(0.0212)$ & $-0.0326(0.0219)$ \\
\hline & $\mathrm{MC}$ & $0.0903^{*}(0.0527)$ & $0.1214(0.0846)$ & $0.1214(0.1073)$ & $0.0903 *(0.0527)$ \\
\hline & $\mathrm{P} / \mathrm{E}$ & $0.0185(0.0133)$ & $0.0105(0.0181)$ & $0.0105(0.0226)$ & $0.0185(0.0133)$ \\
\hline & $\mathrm{SA}$ & $-0.0594(0.0524)$ & $-0.0117(0.0640)$ & $-0.0117(0.0699)$ & $-0.0594(0.0524)$ \\
\hline & Pages & $0.0038(0.0699)$ & $-0.0035(0.0994)$ & $-0.0035(0.1050)$ & $0.0038(0.0699)$ \\
\hline & $\mathrm{SH}$ & $-0.0044(0.0945)$ & $-0.1277(0.1355)$ & $-0.1277(0.1339)$ & $-0.0044(0.0945)$ \\
\hline & Constant & $0.2022(0.7262)$ & 1.1253 (1.2865) & $1.1253(1.7259)$ & $0.2022(0.7262)$ \\
\hline & $R^{2}$ & 0.0723 & 0.0079 & 0.0079 & 0.0723 \\
\hline & $F$-test & 3.3200 & 2.3400 & 8.0600 & 49.8400 \\
\hline
\end{tabular}

Dependent variables (CAR)

Table V.

Panel data analysis for information content and informativeness of analysts' report
Notes: This table shows the result of the study's model in terms of overall analysis. The signs *, ** and *** denote significant at 10, 5 and $1 \%$, respectively. POLS refers to pooled OLS, FEM refers to fixed effect model, FEM-Robust refers to fixed effect model based on standard robust errors and REM refers to random effect model. As for POLS, FEM and REM, the standard errors are in parentheses, whereas for FEMRobust, the robust standard errors are in parentheses. The number of observation was 656 for all models. The cumulative abnormal return (CAR) was calculated based on market-adjusted model. The time framework used was a daily basis spanning from January 2010 until December 2015

not always necessarily reflect the prices of stocks. This could be the reason why the predictive power of information disclosure for Shari ${ }^{-} a h$-compliant stocks in the analyst report is relatively low as investors prefer to rely on their own analysis, such as technical analysis and market information before making investment decisions. Similarly, as highlighted by Farooq (2014), the analyst recommendation for Shari ${ }^{`}$ ah-compliant shares has less value because Shariah firms encounter lower growth than their non-Shariah counterparts. This may likely reduce the interest of the analyst in recommending Shariah shares, which at the end results in the low value of the analyst report production. However, this does not warrant that analyst reports, which cover Shari $a h$-compliant shares are completely irrelevant to investors. There is always room for improvement to enhance the level of information disclosure such as the incorporation of qualitative information in the report, which will lead to full information dispersion in the market and will allow the investors to invest in an efficient way.

As a recommendation, this study proposes for future studies to look into earnings forecast accuracy of the analyst report for different industries or economic sectors involving

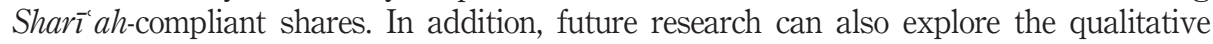
aspect of the information in the analyst reports, a factor that seems to be lacking in many analyst reports especially in the context of Malaysia. Another suggestion is for future studies to look at the risk-profile of Shariah-based firms and their relationship with analyst recommendation. Such research will further provide a better picture of whether investors are able to design a more effective investment strategy based on the analyst recommendation, especially when it involves Shari`ah-compliant shares. 


\section{Implications of the study}

\subsection{Managerial implication}

With the knowledge that not all information disclosures relate to the returns in Shari ahcompliant stocks, analysts can, therefore, take note of this point and try to enhance the information disclosure aspect of their reports. This is a significantly important consideration, as the growth of Islamic finance is in parallel with its conventional counterpart. In realisation of the importance of information in the market, Bursa Malaysia has launched the CBRS (Capital Market Development Fund - Bursa Research Scheme) and the Capital Market Development Fund (CMDF) in 2005. The CMDF has received about RM 7.5m by Bursa Malaysia and this incentive is specifically used to support the dissemination of information to market players via the analyst report. The CMDF supports 50 per cent of the funding in terms of coverage cost. To encourage brokerage houses to cover more Shari $a h$-compliant firms in their recommendation reports, it is suggested that the CMDF should increase the percentage of funding to motivate the research houses to produce more report covering Shari ah-compliant stocks by incorporating more sophisticated information related to the firms. This arrangement may boost the performance and marketability of Sharī ah-compliant stocks.

\subsection{Theoretical implication}

The outcome of this research is expected to enrich the body of knowledge, especially in the related literature within the context of analyst reports in Malaysia. Very few prior studies have examined the content of analysts' written reports in Malaysia. Hatamleh and Salameh (2012) looked at CSR and the role of analyst report, Farooq (2008) focussed on financial crisis and the coverage of analyst report, Madun (2009) analysed analyst incentives and their prediction, whereas a more recent study by Wahab et al. (2015) investigated corporate governance, culture and the forecasts of analyst recommendation and Yezegel (2015) enquired over analyst recommendation ratings. None of the mentioned studies touched upon Shar ${ }^{-}$ah-compliant stocks and analyst recommendations. Therefore, the current research claims to theoretically implicate the matter of information contained in the analyst report by having zoomed into Shari $a h$-compliant stocks. To add, it has further answered the question of whether the analyst report is transmitting adequate information to the investors or vice versa with regard to the stock recommendation.

\section{Note}

1. As defined by Oxford, the information signalling hypothesis conveys the idea that many actions taken by economic agents are chiefly motivated by the wish to send a positive "signal" to other agents, rather than by their ostensible purpose. This can be a means of overcoming the problem of asymmetric information between transactors.

\section{References}

Ainley, M.L., Mashayekhi, A., Hicks, R., Rahman, A. and Ravalia, A. (2007), Islamic Finance in the UK: Regulation and Challenges, Financial Services Authority, London.

Ali, A. and Zarowin, P. (1992), "The role of earnings levels in annual earnings-returns studies", Journal of Accounting Research, Vol. 30 No. 2, pp. 286-296.

Ali, A., Klasa, S. and Yeung, E. (2007), “Corporate disclosures by family firms”, Journal of Accounting and Economics, Vol. 44 Nos 1/2, pp. 238-286.

Asquith, P., Mikhail, M.B. and Au, A.S. (2005), "Information content of equity analyst reports", Journal of Financial Economics, Vol. 75 No. 2, pp. 245-282. 
JIABR 11,4

Atieh, S.H. (2014), "Liquidity analysis using cash flow ratios as compared to traditional ratios in the pharmaceutical sector in Jordan”, International Journal of Financial Research, Vol. 5 No. 3, pp. 146-158.

Barber, B.M., Lehavy, R. and Trueman, B. (2007), "Comparing the stock recommendation performance of investment banks and independent research firms", Journal of Financial Economics, Vol. 85 No. 2, pp. 490-517.

Baule, R. and Wilke, H. (2014), The Information Content of Analyst Forecasts - An Econometric Analysis of Informational Leadership, Working Paper, University of Hagen, Germany, available at: SSRN 2378853 (accessed 2 May, 2017).

Bhushan, R. (1989), "Firm characteristics and analyst following", Journal of Accounting and Economics, Vol. 11 Nos 2/3, pp. 255-274.

Bradshaw, M.T. and Brown, L.D. (2006), "Do sell-side analysts exhibit differential target price forecasting ability", Arbeitspapier, Harvard Business School, Boston.

Brav, A. and Lehavy, R. (2003), "An empirical analysis of analysts' target prices: short-term informativeness and long-term dynamics", The Journal of Finance, Vol. 58 No. 5, pp. 1933-1968.

Brennan, M.J., Chordia, T. and Subrahmanyam, A. (1998), "Alternative factor specifications, security characteristics, and the cross-section of expected stock returns", Journal of Financial Economics, Vol. 49 No. 3, pp. 345-373.

Breton, G. and Taffler, R.J. (2001), "Accounting information and analyst stock recommendation decisions: a content analysis approach", Accounting and Business Research, Vol. 31 No. 2, pp. 91-101.

Bukit, R.B. and Iskandar, T.M. (2009), "Surplus free cash flow, earnings management and audit committee", International Journal of Economics and Management, Vol. 3 No. 1, pp. 204-223.

Byard, D., Li, Y. and Weintrop, J. (2006), "Corporate governance and the quality of financial analysts' information", Journal of Accounting and Public Policy, Vol. 25 No. 5, pp. 609-625.

Caylor, R. (2010), "Strategic revenue recognition to achieve earnings benchmarks", Journal of Accounting and Public Policy, Vol. 29 No. 1, pp. 82-95.

Chan, L.K.C., Hamao, Y. and Lakonishok, J. (1991), "Fundamentals and stock returns in Japan", The Journal of Finance, Vol. 46 No. 5, pp. 1739-1764.

Chang, Y.H. and Chan, C.C. (2008), "Financial analysts' stock recommendation revisions and stock price changes", Applied Financial Economics, Vol. 18 No. 4, pp. 309-325.

Chen, Y.S. and Chu, S.H.M. (2009), "Information content of stock recommendation revisions and target price changes in security analyst reports - a study of Taiwan's equity market", The Empirical Economic Letters, Vol. 8 No. 12, pp. 1-44.

Cheynel, E. and Levine, C.B. (2012), "Analysts' sale and distribution of non-fundamental information", Review of Accounting Studies, Vol. 17 No. 2, pp. 352-388.

Da Silva, P.P. (2013), "The information content of analyst's price targets and recommendations on stocks prices evidence for the Portuguese market", available at: www.researchgate.net/

Da, Z. and Schaumburg, E. (2011), "Relative valuation and analyst target price forecasts", Journal of Financial Markets, Vol. 14 No. 1, pp. 161-192.

Dewi, M.K. and Ferdian, I.R. (2012), "Evaluating performance of Islamic mutual funds in Indonesia and Malaysia”, Journal of Applied Economics and Business Research, Vol. 2 No. 1, pp. 11-33.

Earnst and Young Report (2016), available at: www.ey.com/gl/en/about-us/our-global-approach/globalreview (accessed 26 March 2016).

Ertimur, Y., Sunder, J. and Sunder, S.V. (2007), "Measure for measure: the relation between forecast accuracy and recommendation profitability of analysts", Journal of Accounting Research, Vol. 45 No. 3, pp. 567-606.

Ettredge, M., Richardson, V.J. and Scolz, S. (2002), "Dissemination of information for investors at corporate web sites”, Journal of Accounting and Public Policy, Vol. 21 Nos 4/5, pp. 357-369. 
Fama, E.F. (1984), "Forward and spot exchange rates", Journal of Monetary Economics, Vol. 14 No. 3, pp. 319-338.

Farooq, O. (2008), Financial Crisis and Performance of Analysts' Recommendations, Stockholm School of Economics, Stockholm.

Farooq, O. (2014), "Shariah-compliance and value of analysts' recommendations: evidence from the MENA region”, Journal of Islamic Accounting and Business Research, Vol. 5 No. 1, pp. $61-76$.

Farooq, O. and AbdelBari, R. (2013), "Effect of property rights on the relationship between legal traditions and corporate governance: evidence from the MENA region", International Journal of Business Governance and Ethics, Vol. 8 No. 3, pp. 224-241.

Feng, X., Hu, N. and Johansson, A. (2015), Ownership, Analyst Coverage, and Stock Synchronicity in China (No. 2015-36), Stockholm China Economic Research Institute, Stockholm School of Economics, Stockholm.

Fonseka, M.M. and Tian, G.L. (2011), "What factors motivate the analysts' stock recommendation in a small emerging market? Evidence from Sri Lanka", African Journal of Business Management, Vol. 26 No. 5, pp. 10908-10920.

Foster, G., Olsen, C. and Shevlin, T. (1984), "Earnings releases, anomalies, and the behaviour of security returns", Accounting Review, Vol. 59 No. 4, pp. 574-603.

Francis, J. and Soffer, L. (1997), "The relative informativeness of analysts' stock recommendations and earnings forecast revisions", Journal of Accounting Research, Vol. 35 No. 2, pp. 193-211.

Guagliano, C., Linciano, N. and Contento, C.M. (2013), "The impact of financial analyst reports on small caps prices in Italy", Economic Notes, Vol. 42 No. 3, pp. 217-246.

Hatamleh, I. and Salameh, S. (2012), "Corporate social responsibility and analyst's coverage in Malaysia", Doctoral dissertation, USM.

Healy, P.M. and Palepu, K.G. (2003), “The fall of Enron”, Journal of Economic Perspectives, Vol. 17 No. 2, pp. 3-26.

Hodgkinson, L. (2001), "Analysts' forecasts and the broker relationship”, Journal of Business Finance and Accounting, Vol. 28 Nos 7/8, pp. 943-961.

Hou, T.C.T., Hung, W. and Gao, S.S. (2014), "Investors' reactions to analysts' forecast revisions and information uncertainty evidence of stock price drift", Journal of Accounting, Auditing and Finance, Vol. 29 No. 3, pp. 238-259.

Hsieh, J., Ng, L.K. and Wang, Q. (2005), "How informative are analyst recommendations and insider trades?", AFA 2006 Boston Meetings Paper, Boston.

Huang, J., Mian, G.M. and Sankaraguruswamy, S. (2009), "The value of combining the information content of analyst recommendations and target prices", Journal of Financial Markets, Vol. 12 No. 4, pp. 754-777.

Ioannou, I. and Serafeim, G. (2010), "The impact of corporate social responsibility on investment recommendations", Strategic Management Journal, Vol. 36 No. 1, pp. 1053-1081.

Irvine, P.J. and Pontiff, J. (2009), "Idiosyncratic return volatility, cash flows, and product market competition”, Review of Financial Studies, of Financial Studies, Vol. 22 No. 3, pp. 1149-1177.

Islamicfinance.com (2016), Retrieved on 26/3/2016, available at: www.islamicfinance.com/2016/06/ifsbislamic-financial-services-stability-report-2016/ (accessed 1 February 2017).

Jegadeesh, N. and Kim, W. (2006), "Value of analyst recommendations: international evidence", Journal of Financial Markets, Vol. 9 No. 3, pp. 274-309.

Jegadeesh, N. and Titman, S. (2001), "Profitability of momentum strategies: an evaluation of alternative explanations", The Journal of Finance, Vol. 56 No. 2, pp. 699-720.

Jegadeesh, N., Kim, J., Krische, S.D. and Lee, C. (2004), "Analysing the analysts: when do recommendations add value?”, The Journal of Finance, Vol. 59 No. 3, pp. 1083-1124. 
JIABR 11,4

Jooste, L. (2007), "An evaluation of the usefulness of cash flow ratios to predict financial distress", Acta Commercii, Vol. 7 No. 1, pp. 1-13.

Lau, S.T., Lee, C.T. and McInish, T.H. (2002), "Stock returns and beta, firms size, E/P, CF/P, book-tomarket, and sales growth: evidence from Singapore and Malaysia", Journal of Multinational Financial Management, Vol. 12 No. 3, pp. 207-222.

Lien, Y.-C. and Li, S. (2013), "Does diversification add company value in emerging economies? Effect of corporate governance", Journal of Business Research, Vol. 66 No. 12, pp. 2425 -2430.

Livnat, J. and Zhang, Y. (2012), "Information interpretation or information discovery: which role of analysts do investors value more?”, Review of Accounting Studies, Vol. 17 No. 3, pp. 612-641.

Loh, R.K. and Mian, G.M. (2006), "Do accurate earnings forecasts facilitate superior investment recommendations?", Journal of Financial Economics, Vol. 80 No. 2, pp. 455-483.

Madun, A. (2009), The Impact of Financial Analyst Coverage on Stock Properties: The Experience of the Malaysian Research Incentive Scheme, University of Bath, Bath.

Marquardt, C. and Wiedman, C. (2004), "How are earnings managed? An examination of specific accruals", Contemporary Accounting Research, Vol. 21 No. 2, pp. 461-491.

Mburu (2014), "Relationship between exchange rate volatility and stock market performance", MBA Dissertation.

Mun, L.Y. and Thaker, H.M.T. (2016), "Asset liability management of conventional and Islamic banks in Malaysia", Al-Iqtishad: Journal of Islamic Economics, Vol. 9 No. 1, pp. 33-52.

Parnal, H.K. and Jain, S. (2013), "Cash flow ratios to predict investment's soundness", Asia-Pacific Finance and Accounting Review, Vol. 1 No. 4, pp. 55-76.

Savor, P.G. (2012), "Stock returns after major price shocks: the impact of information", Journal of Financial Economics, Vol. 106 No. 3, pp. 635-659.

Sing, L.Y. and Richter, F. (2010), "Islamic finance seems overwhelmed by scholar reforms", The Edge Financial Daily, 30th Sept 2010 (accessed 3 March 2017).

Standard and Poor's Ratings (2017), available at: www.standardandpoors.com/en_US/web/guest/home (accessed 23 March 2017).

Sweeney, A.P. (1994), "Debt-covenant violations and managers' accounting responses", Journal of Accounting and Economics, Vol. 17 No. 3, pp. 281-308.

Thaker, H.M.T., Mohamad, A. and Omar, A. (2017), "A qualitative inquiry into the issues of information content of analysts' report: evidence from Malaysia", Labuan Bulletin of International Business and Finance, Vol. 15 (December), pp. 1-21.

Wahab, E.A.A., Pitchay, A.A. and Ali, R. (2015), "Culture, corporate governance and analysts forecast in Malaysia", Asian Review of Accounting, Vol. 23 No. 3, pp. 232-255.

Womack, K.L. (1996), “Do brokerage analysts’ recommendations have investment value?”, The Journal of Finance, Vol. 51 No. 1, pp. 137-167.

Yezegel, A. (2015), "Why do analysts', revise their stock recommendations after earnings announcements?”, Journal of Accounting and Economics, Vol. 59 Nos 2/3, pp. 163-181.

\section{Corresponding author}

Hassanudin Mohd Thas Thaker can be contacted at: hassan.finance.hu@gmail.com

For instructions on how to order reprints of this article, please visit our website:

www.emeraldgrouppublishing.com/licensing/reprints.htm

Or contact us for further details: permissions@emeraldinsight.com 